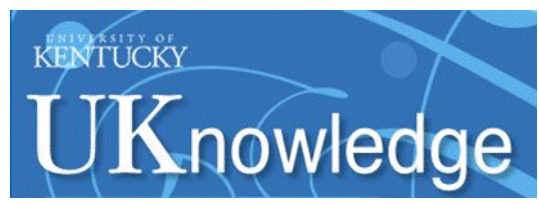

University of Kentucky

UKnowledge

\title{
Variables Related to School Media Center LGBT Collections
}

Shannon M. Oltmann

University of Kentucky, shannon.oltmann@uky.edu

Follow this and additional works at: https://uknowledge.uky.edu/slis_facpub

Part of the Library and Information Science Commons

Right click to open a feedback form in a new tab to let us know how this document benefits you.

\section{Repository Citation}

Oltmann, Shannon M., "Variables Related to School Media Center LGBT Collections" (2015). Information Science Faculty Publications. 21.

https://uknowledge.uky.edu/slis_facpub/21

This Article is brought to you for free and open access by the Information Science at UKnowledge. It has been accepted for inclusion in Information Science Faculty Publications by an authorized administrator of UKnowledge. For more information, please contact UKnowledge@lsv.uky.edu. 


\section{Variables Related to School Media Center LGBT Collections}

Digital Object Identifier (DOI)

http://dx.doi.org/10.1515/libri-2014-0069

Notes/Citation Information

Published in Libri, v. 65, no. 1, p. 25-33.

The copyright holders have granted the permission for posting the article here. 


\section{Shannon M. Oltmann}

\section{Variables Related to School Media Center LGBT Collections}

\begin{abstract}
The inclusion of LGBT (lesbian, gay, bisexual, and transgender) literature in school media centers can be controversial, but such material can be beneficial in helping LGBT students come to terms with their sexuality and with helping to foster understanding in non-LGBT students. To examine the extent of such collections in school media centers, this research conducted a checklist exercise to examine the holdings of school libraries in two very different states, one in the northeastern United States and one in the southern United States. The study examined variables that may correlate with the number of LGBT books available in the libraries; these variables were size of school enrollment, type of locale, the existence of a fairness ordinance, demographic diversity, and political affiliation.
\end{abstract}

Keywords: LGTB literature, school libraries, U.S.A., collection development policy, censorship

DOI 10.1515/libri-2014-0069

Received May 21, 2014; accepted July 28, 2014

\section{Introduction}

There are an estimated 2.5 million lesbian, gay, or bisexual teenagers (LGBT) in the United States (Rauch 2010; Mehra and Braquet 2011). Other researchers report approximately $5-6 \%$ of teenagers in grades 7-12 (Rossi 2010) or 3-10\% of the student population (Gardes 2008) self-identify as LGBT. A Williams Institute report, based on the 2010 US Census, reports that same-sex couples are found in $93 \%$ of counties across the United States (Gates and Cooke 2011). From these numbers, one can infer that virtually all school media centers serve at least some LGBT students, regardless of location or population size (Rauch 2011). This study examines the holdings of randomly selected school media centers in two different states to determine the depth of LGBT holdings and the various factors that may be correlated to LGBT collections.

Dr. Shannon M. Oltmann, Assistant Professor, School of Library and Information Science, University of Kentucky, Lexington, KY, USA, E-mail: shannon.oltmann@uky.edu
Two reasons for serving LGBT youth in school media centers can be discerned from the literature. First, providing positive resources for LGBT young adults who are in the process of "coming out" can lessen the confusion and pain often experienced at this time. Mehra and Braquet $(2011,16)$ suggest that, "libraries can be important supports for queer youth to establish positive self-identification and to help in the integration with and acceptance of the queer community and individuals within the larger social fabric" (Downey 2013). Learning about and developing one's selfidentity, learning how to cooperate with others, and "how to respect and appreciate differences and similarities amongst people... are just as important as traditional academic curricula, if not more important as the 21st century continues to unfold" (Savage and Schanding 2013, 2).

Second, providing LGBT resources allows all patrons (both LGBT and non-LGBT) to learn about the history, culture, and other aspects of LGBT life (Ritchie 2001; Norton and Vare 2004; Stringer-Stanback 2011; Savage and Schanding 2013; Vaillancourt 2013). Rauch (2011) describes the ways in which LGBT resources can help non-LGBT patrons: "Access to stories with characters who may be like his/her classmates or friends can help a teen reader be more empathetic and understanding as $\mathrm{s} /$ he experiences vicariously the struggles and confusion many LGBTQ teens go through" (Rauch 2011, 14; see also Clyde and Lobban 2001).

Despite these arguments, it is unclear how thoroughly school media centers collect LGBT material. This is an area needing further research (Clyde and Lobban 2001). The current study addresses this deficit by examining the holdings of school media centers in two very different places in the United States.

\section{Previous Research}

There has been some previous work investigating the collection of LGBT resources in libraries; however, the previous work all indicates low collection numbers for LGBT books. Boon and Howard (2004) looked at LGBT books in nine Canadian public libraries. Randomly selected non-LGBT books in the control group were $70 \%$ more likely to be held in these public libraries. LGBT books had 34\% fewer published reviews per title as compared to those in the randomly selected control group. They suggest that the lack of reviews 
may be a factor, but other (unmeasured) factors likely play a role as well, such as budget, staff size, collection policies, city population, and demographic attributes.

In 2007, Martin and Murdock reported that $30 \%$ of LGBT teens could not find desired LGBT materials in their public libraries. Stringer-Stanback (2011) examined holdings of LGBT material in the four most populous counties from five southeastern US states. She found no relationship between the existence of a fairness ordinance and the level of LGBT collecting. However, she did find that the more demographically diverse counties were likely to have more LGBT books. Ritchie (2001) focused on adult non-fiction held by mediumsized public libraries in Illinois, rather than large urban areas as Stringer-Stanback did. Ritchie reported that $97.6 \%$ of libraries reported holding at least some LGBT-topical books, with an average of 12.7 volumes held by each library. Moss (2008) conducted an inductive evaluation of a single public library, which found nearly $80 \%$ of the desired LGBT books held by this large urban library.

Oberg and Klein (2003) examined the holdings of public and academic libraries in Oregon, and found wide variation in holdings, which were influenced by the size of the library, the type of library, and whether the library was in a "traditionally conservative" area $(2003,10)$. Another study looked at LGBT books in public high school libraries in a southern US state, and found that the libraries held, on average, $0.4 \%$ of the suggested books (Hughes-Hassel et al. 2013). Other authors have likewise reported low collection numbers in public or school libraries (Mehra and Braquet 2006, 2011; Greyson 2007; Lang 2009; Downey 2013; Vaillancourt 2013).

Several reasons have been suggested to account for the low collection numbers of LGBT books. Mehra and Braquet $(2011,403)$ point to "the encompassing hegemonic trends of heterosexuality we encounter in almost every niche of the American academy" (see also Walton 2004; Lang 2009; Savage and Schanding 2013). Several people have noted the lack of comprehensive, detailed collection development guidelines for LGBT content (e.g. Greyson 2007) and the perennial fear of book challenges (e.g. Luckenbill 2007). As Jenkins (2008, 228) noted, censorship and challenges can be seen "as the tensions of society writ small, a struggle waged in the limited arena of the pages of a book".

\section{Study Overview}

Although the studies described above encompass different types of libraries in both Canada and the United States, the research by Hughes-Hassel et al. (2013) suggests that the same low collection numbers are found in US school media centers as well. Yet little is known about the collection numbers for school media centers in particular. To rectify this gap in our knowledge, the current study examines the holdings of school media centers in public high schools in two different American states.

This research expands the work of Hughes-Hassel et al. (2013) by examining the holdings of school media centers in two (very different) states, by conducting a listchecking exercise; as Moss (2008) notes, this is the most common evaluation method. This allowed for comparisons between the states, as well as providing a larger overall sample. In addition, this study examined five factors that may affect the depth of collections: school enrollment size, type of locale, the existence of a fairness ordinance, ${ }^{1}$ demographic diversity, and predominant political affiliation. Below, each state is described in more detail and the variables are explained.

\section{Overview of the States Selected for Study}

State $\mathrm{One}^{2}(\mathrm{NE})$ is located in the northeastern section of the United States (see Table 1). In the United States, it is considered a "blue" state, which means it has a strong

Table 1: Comparison of State One and State Two on selected variables.

\begin{tabular}{|c|c|c|}
\hline Variables & State One (NE) & State Two (SO) \\
\hline Location & Northeastern & Southern \\
\hline Political affiliation & Democrat & Republican \\
\hline Type of locale & $\begin{array}{l}\text { Primarily urban/ } \\
\text { suburban }\end{array}$ & Primarily rural \\
\hline Fairness ordinance? & Yes (statewide) & $\begin{array}{l}\text { Only in certain } \\
\text { cities }\end{array}$ \\
\hline Same-sex marriage? & Yes & No \\
\hline $\begin{array}{l}\text { School system } \\
\text { organization }\end{array}$ & Township based & County based \\
\hline Regions & 6 & 8 \\
\hline Demographic diversity & Varies widely & Mostly low \\
\hline Total schools in study & 63 & 74 \\
\hline
\end{tabular}

1 A fairness ordinance generally prohibits discrimination against lesbian, gay, bisexual (and sometimes) transgender individuals. In some areas, such protection is statewide (as in NE state), while in other areas, the state does not offer such protection but certain cities or counties do (as in SO state).

2 Following Hughes-Hassel et al. (2013), the states are given euphemisms because the author does not wish to identify them publicly. The author may be contacted by email for further information. 
Democratic voting record (though various locales in the state do traditionally vote Republican). It is predominantly urban or suburban, with relatively few rural areas. There is a statewide "fairness ordinance" which prohibits discrimination against LGBT individuals, and the state allows same-sex marriage. School systems are predominantly based on a township system, with most townships having their own school system. NE is divided into six districts by the State's Department of Education. Demographic diversity varies across the state.

State Two (SO) is located in the southern portion of the United States. It is considered a reliably "red" state, traditionally voting Republican (though various locales often vote Democratic). The state is predominantly rural, with a few large urban and suburban areas. SO does not have a state-level fairness ordinance, though a few cities have localized fairness ordinances; same-sex marriage was banned by a constitutional amendment in this state (though at the time of writing, this ban is undergoing legal challenges). School systems are primarily countybased, though there are regional and town-based school systems as well. SO is usually divided into eight regions. Demographic diversity is fairly low across the state, though urban areas tend to have somewhat higher diversity.

\section{Methods}

Once the two states were identified, information about each state was noted (see Table 1). These variables were selected based on previous studies (Oberg and Klein 2003; Stringer-Stanback 2011; Hughes-Hassel et al. 2013). Political affiliation was determined by consulting a map of voting results from the 2012 US Presidential election; townships or counties that predominantly voted for Romney were coded as Republican, while townships or counties that predominantly voted for Obama were coded as Democrat. The type of locale was determined based on the definitions created by the National Center for Education Statistics (2006); the four basic locales are city, suburb, town, and rural. For more statistical power, the categories of town and rural were combined here. The fairness ordinance variable addresses whether there is an existing fairness ordinance. Finally, demographic diversity indicates the percentage of non-white people identified in that locale during the 2010 census. The other variables listed in Table 1 are to facilitate comparison between the states, but they were not used in the analysis.

Next, a list of all public high schools in each state was obtained from the Department of Education's website. The schools were grouped by region (six regions in NE and eight in SO), and then every third school was selected for inclusion. Once a school was selected, its library's online catalog was located and the URL was noted. If the school did not have a functioning online catalog, it was deselected and the next school in the list was chosen. When this process was complete, 63 schools from NE and 74 schools from SO were selected. None of the schools from NE or SO listed the collection size of their libraries (and this data was not available from the respective State Departments of Education), so this variable was not included.

To develop the list of LGBT books, four sources were consulted. Three sources were annual literary awards with an explicit LGBT focus: Lambda Literary Foundation Awards, Stonewall Book Awards, and the Rainbow Awards. Award winners and nominees ${ }^{3}$ for each award were noted; titles that were not categorized as young adult/teen literature were removed from the list. In addition, the book Gay, Lesbian, Bisexual, Transgender, and Questioning Teen Literature: A Guide to Reading Interests by Webber (2010) was used to identify important LGBT books. ${ }^{4}$ The books that Webber suggested overlapped significantly with the lists based on the awards. This process yielded 110 books recommended for inclusion. Unlike Hughes-Hassel et al. (2013), this study did not examine holdings based on subject headings because of the large number of libraries and the already-large list of LGBT books. Finally, each school's online catalog was searched to see if the library held any of the 110 books on the list. The catalog was searched for the title of the book, and if results came back, the results were investigated to ensure the correct book was identified.

\section{Results}

This study found that nearly every school media center sampled held at least one LGBT book on the list. In SOstate, three schools had zero books, but the school

3 For the Lambda Literary Foundation Awards, the winners and nominees from 1998 to 2013 were examined. For the Stonewall Awards, which began selecting young adult books in 2010, the winners and nominees from 2010 to 2013 were chosen. Starred books in the Rainbow book lists from 2011 to 2013 were selected. 4 Hughes-Hassel et al. (2013) used this book as well. They explained they used it because it received positive reviews in School Library Journal, Young Adult Library Services, and Booklist. Furthermore, "Webber's guide discusses the importance of selecting books that present positive and accurate portrayals of the LGBT community, and the book provides a recommended reading list of fifteen LGBT young adult fiction titles and six nonfiction titles that she believes every high school library should collect” (Hughes-Hassel et al. 2013, 6). 


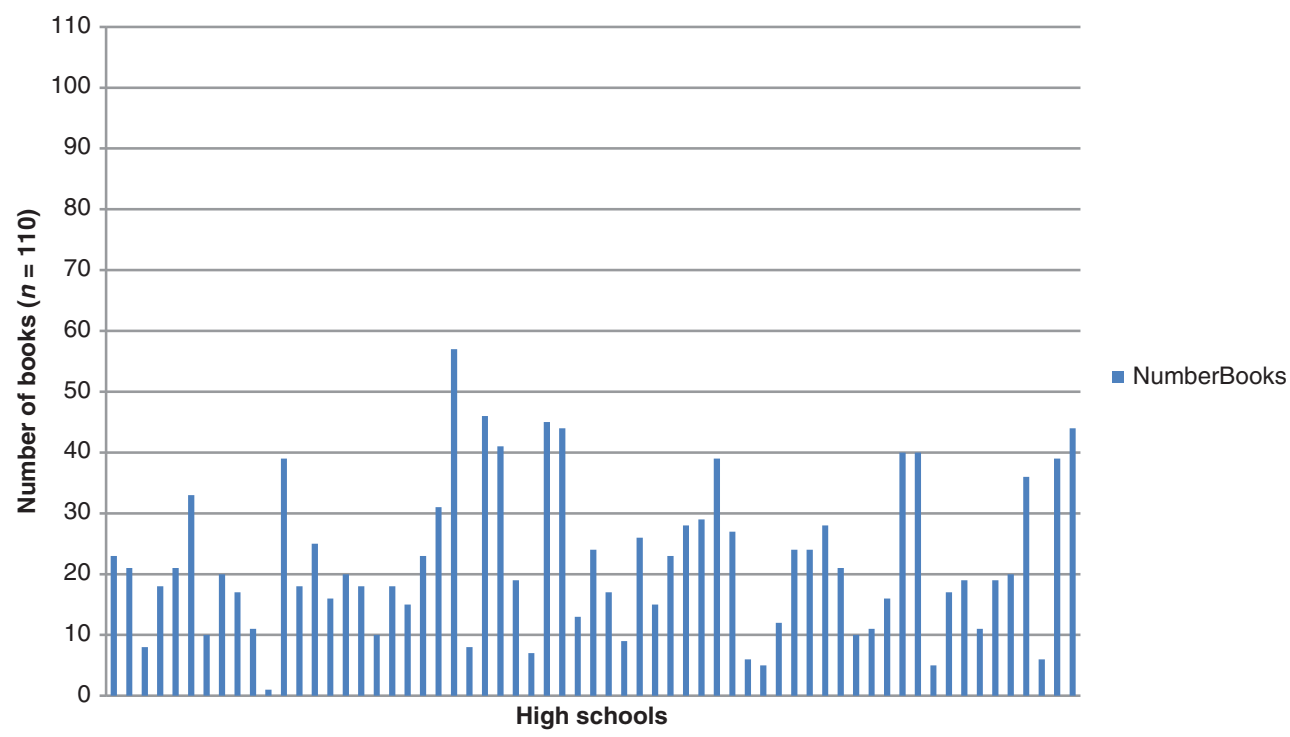

Figure 1: Number of books held by NE school media centers.

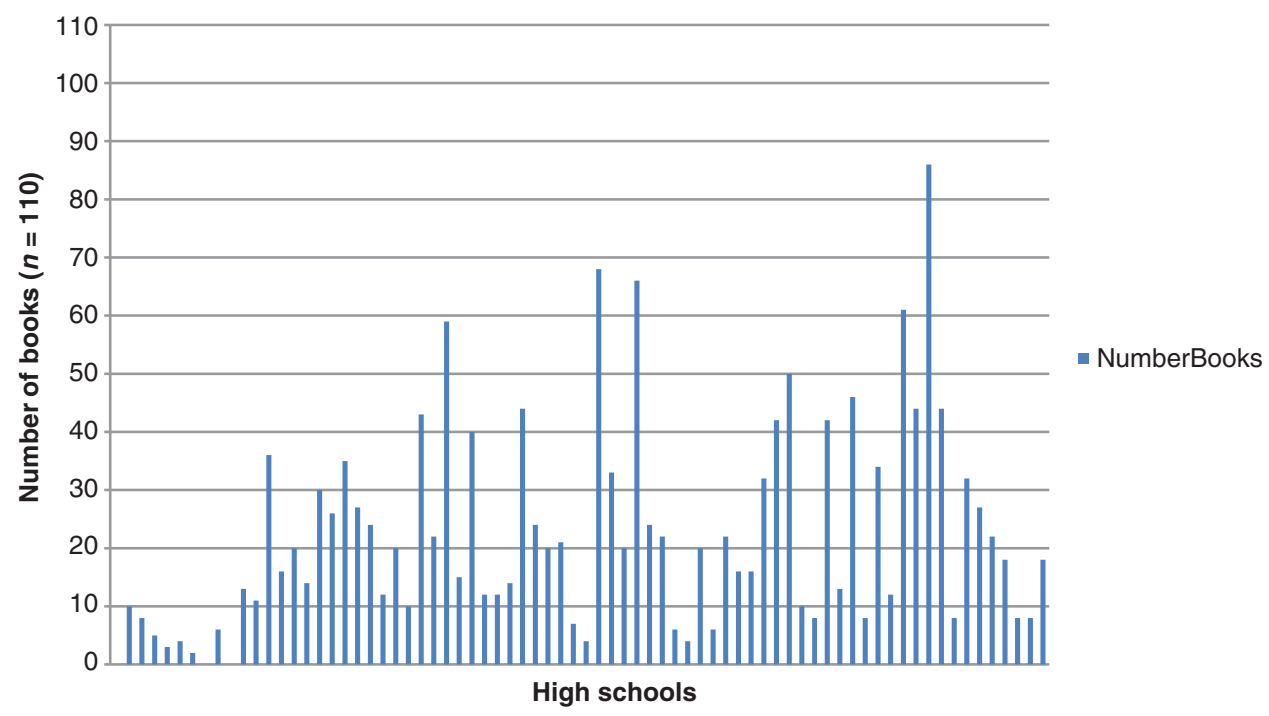

Figure 2: Number of books held by SO school media centers.

media center with the most LGBT books had 86 (see Figure 1). The SO school media centers held an average of 22.5 books from the list (20.5\% of the total 110 books). All of the NE school media centers held at least one book from the list. The largest holding of listed books was 57 (see Figure 2). On average, NE school media centers held 22 books from the list ( $20 \%$ of the total 110 books). These figures show the totals for the entire list that was checked (combining ${ }^{5}$ Lamba Literary Award winners and nominees, Stonewall Award winners and nominees, Rainbow

5 Duplicates across the lists were removed. notable books, and the books recommended by Webber). Overall, the numbers between the two states are fairly similar and show less disparity than might be expected. The lists of most frequently held books are also similar, with five books showing up on both lists (see Table 2).

\section{ANOVA Analysis of Variables}

Multiple variables were investigated to determine if there were correlations with the number of books held; these 
Table 2: Top ten most frequently held books by state (number of holdings indicated in parentheses).

\begin{tabular}{ll}
\hline NE state & So state \\
\hline The perks of being a wallflower (57) & Skim (38) \\
* Will Grayson, Will Grayson (52) & * Will Grayson, Will Grayson (30) \\
My heartbeat (41) & * Every day (29) \\
* Ask the passengers (40) & October mourning: A song for Matthew Shepard (26) \\
* Hard love (40) & Beauty queens (25) \\
* Every day (37) & * Aristotle and Dante discover the secrets of the universe (22) \\
Am I blue? (35) & I am J (22) \\
Someday this pain will be useful to you (34) & * Ask the passengers (21) \\
* Aristotle and Dante discover the secrets of the universe (33) & Almost perfect (20) \\
Annie on my mind (32) & * Hard love (19) (three-way tie) \\
& Last exit to normal (19) \\
\hline
\end{tabular}

Note: *Books that appear on both lists.

variables were enrollment size of the school; locale of the school; the political affiliation of the community; existence of a fairness ordinance; and the amount of demographic diversity in that community (see the previous section for an explanation of these variables). To investigate these, the proportion was calculated, then log-transformed. Then a one-way analysis of variance (ANOVA) was calculated with the log of the proportion. As shown in Table 3, none of the variables were significant at the $p=0.05$ level in NE state. Enrollment, locale, political affiliation, and demographic diversity were not correlated with the number of LGBT books held by the sampled school media centers in NE state. Possible correlation with the existence of a fairness

Table 3: Analysis of variables for NE state.

\begin{tabular}{lrrr}
\hline Variable & Mean & $\begin{array}{r}\text { Standard } \\
\text { deviation }\end{array}$ & $\begin{array}{r}\text { F-statistic } \\
\text { (logit }(p))\end{array}$ \\
\hline $\begin{array}{l}\text { Enrollment } \\
\quad \text { Large }\end{array}$ & 19.41 & 10.17 & $0.74(p=0.48)$ \\
$\quad$ Medium & 25.00 & 13.96 & \\
$\quad$ Small & 22.00 & 12.74 & \\
Locale & & & $0.25(p=0.7824)$ \\
$\quad$ Suburb & 22.19 & 11.46 & \\
$\quad$ Rural & 22.75 & 13.18 & \\
$\quad$ City & 20.10 & 14.98 & \\
Political affiliation & & & $0.25(p=0.4170)$ \\
$\quad$ Democrat & 21.85 & 12.69 & \\
$\quad$ Republican & 20.60 & 12.15 & \\
Demographic diversity & & & $1.21(p=0.3039)$ \\
$\quad$ High & 19.77 & 11.06 & \\
$\quad$ Average & 24.60 & 13.87 & \\
$\quad$ Low & 21.86 & 11.82 & \\
\hline
\end{tabular}

Note: ${ }^{*}{ }^{*}$ indicates significance at the $p=0.05$ level. ordinance was not calculated for NE state because the ordinance is statewide. School media centers in large schools in NE held an average of 19 books, while medium-sized schools had 25 books, on average, and small schools had 22 books. Similar averages occur across all factors.

A similar analysis was then conducted for SO state (with the added variable of the fairness ordinance). Most variables were not significantly correlated (see Table 4). However, enrollment was a significant variable at the $p$ $=0.05$ level. Further pairwise analysis revealed that the difference between large enrollment and small enrollment was significant. School media centers in schools with large enrollments held an average of 33.27 books, while school media centers in small schools held an average of 15 books.

\section{Transgender-themed Books}

After examining the holdings of the entire list, the list was then subdivided into smaller categories. For example, there were 10 books on the list with transgendered characters or transgender themes. ${ }^{6}$ Investigation was carried out on just these books; here, we report just the variables that were significant. In NE state, school media centers carried an average of 2.05 transgender-themed

6 The transgender-themed books on the holdings list were 10,000 Dresses; Almost Perfect; Beautiful Music for Ugly Children; Brooklyn, Burning; Grl2grl; How Beautiful the Ordinary; I Am J; Jumpstart the World; Luna; and Parrotfish. 
Table 4: Analysis of variables for SO state.

\begin{tabular}{lrrr}
\hline Variable & Mean & $\begin{array}{r}\text { Standard } \\
\text { deviation }\end{array}$ & $\begin{array}{r}\text { F-statistic } \\
(\text { logit }(p))\end{array}$ \\
\hline $\begin{array}{l}\text { Enrollment } \\
\quad \text { Large }\end{array}$ & 33.27 & 20.69 & $6.99(p=0.0017)^{\star \star *}$ \\
$\quad$ Medium & 18.33 & 10.87 & \\
$\quad$ Small & 15.00 & 15.12 & \\
$\quad$ Fairness ordinance & & & $1.14(p=0.2888)$ \\
$\quad$ Not present & 21.46 & 18.06 & \\
$\quad$ Present & 28.45 & 16.69 & \multirow{2}{*}{$1.69(p=0.1933)$} \\
Locale & & & \\
$\quad$ Suburb & 24.88 & 17.33 & \\
$\quad$ Rural & 19.59 & 18.27 & \\
$\quad$ City & 32.13 & 16.59 & \\
Political affiliation & & & $1.03(p=0.3134)$ \\
$\quad$ Democrat & 27.38 & 16.04 & \\
$\quad$ Republican & 21.46 & 18.26 & \\
Demographic diversity & & & $2.27(p=0.1111)$ \\
$\quad$ High & 25.32 & 15.30 & \\
$\quad$ Average & 25.54 & 21.63 & \\
$\quad$ Low & 16.00 & 14.68 & \\
\hline
\end{tabular}

Note: ${ }^{* \star *}$ indicates significance at the $p=0.05$ level.

books. Enrollment was determined to be a significant variable (at $p=0.05$ level) affecting the number of books held by school media centers (see Table 5). A pairwise comparison revealed that the significant difference was between large and small schools. Those with a large enrollment held an average of 2.95 books, while small-sized schools held only 1.5 transgender-themed books.

Table 5: Variable analysis for transgender-themed books in NE state.

\begin{tabular}{lrrr}
\hline Variable & Mean & Standard deviation & F-statistic (logit $(p))$ \\
\hline Enrollment & & & \multirow{2}{*}{$4.06(p=0.0222)^{\star \star \star}$} \\
Large & 2.95 & 079 & \\
Medium & 1.63 & 0.80 & \\
Small & 1.50 & 0.78 & \\
\hline
\end{tabular}

Note: ${ }^{\star \star \star}$ indicates significance at $p=0.05$ level.

In SO state, school media centers held an average of 1.51 books with transgender themes. Again, the enrollment variable was found to be significant (see Table 6) and subsequent pairwise comparison showed significance between large and medium-sized schools and between large and small schools. In SO State, schools with large enrollments held an average of 2.54 transgender-themed books, while medium-sized schools held 1.04 books on average and small schools held 0.88 on average.
Table 6: Variable analysis for transgender-themed books in SO state.

\begin{tabular}{lcrc}
\hline Variable & Mean & Standard deviation & F-statistic (logit $(\boldsymbol{p}))$ \\
\hline Enrollment & & & $9.48(p=0.0002)^{\star \star \star}$ \\
$\quad$ Large & 2.54 & 0.84 & \\
Medium & 1.04 & 0.64 & \\
Small & 0.88 & 0.60 & \\
\hline
\end{tabular}

Note: ${ }^{\star \star \star}$ indicates significance at $p=0.05$ level.

\section{Non-fiction Books}

Another category of books explored here was non-fiction books; there were 13 on the holdings list. ${ }^{7}$ Again, here we report only the variables of significance. In NE state, school media centers held an average of 1.49 non-fiction titles. Initial one-way ANOVA tests indicated that locale was significant, and subsequent pairwise comparison found significant difference between suburb and city holdings (see Table 7). School media centers in schools in city locales held an average of 0.60 non-fiction LGBT titles, while school media centers in suburb locales held 1.68 titles on average.

Table 7: Variable analysis for nonfiction books in NE state.

\begin{tabular}{lcrl}
\hline Variable & Mean & Standard deviation & F-statistic (logit $(p))$ \\
\hline Locale & & & \multirow{2}{*}{$3.46(p=0.0379)^{\star \star \star}$} \\
Suburb & 1.68 & 0.78 & \\
Rural & 1.63 & 0.85 & \\
City & 0.60 & 0.49 & \\
\hline
\end{tabular}

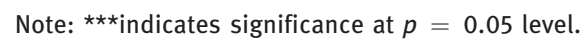

In SO state, both enrollment and locale were found to be significantly correlated with the school media center holdings of nonfiction LGBT titles (see Table 8). Schools in SO State held an average of 0.49 nonfiction titles. By enrollment, large schools held 0.92 titles, medium-sized schools held 0.38 titles, and small schools held 0.15 titles.

7 The nonfiction books on the list were Am I Blue? Coming out from the Silence; Gay America: Struggle for Equality; GLBTQ: The Survival Guide for Queer and Questioning Teens; Is It a Choice? Answers to the Most Frequently asked Questions about Gay and Lesbian People; Lovers' Legends: The Gay Greek Myths; October Mourning: A Song for Matthew Shepard; Outspoken; Telling Tales out of School; The Full Spectrum: A New Generation of Writing about Gay, Lesbian, Bisexual, Transgender, Questioning, and Other Identities; The Letter Q: Queer Writers' Notes to Their Younger Selves; The Little Black Book for Girlz; The Little Black Book for Guys: Guys Talk about Sex; and The XY Survival Guide. 
Table 8: Variable analysis for nonfiction books in SO state.

\begin{tabular}{lcrl}
\hline Variable & Mean & Standard deviation & F-statistic $($ logit $(p))$ \\
\hline Enrollment & & & $8.79(p=0.0004)^{\star \star \star}$ \\
$\quad$ Large & 0.92 & 0.57 & \\
$\quad$ Medium & 0.38 & 0.40 & \\
$\quad$ Small & 0.15 & 0.26 & \\
Locale & & & $4.28(p=0.0179)^{\star \star \star *}$ \\
$\quad$ Suburb & 0.63 & 0.49 & \\
Rural & 0.35 & 0.42 & \\
City & 1.13 & 0.61 & \\
\hline
\end{tabular}

Note: ${ }^{\star \star \star}$ indicates significance at $p=0.05$ level.

Pairwise comparison found significance between large and medium schools and between large and small schools. Rural schools held 0.35 titles on average, suburban schools held 0.63 nonfiction titles, and schools located in cities held 1.13 titles on average. Pairwise comparison found significant difference between schools in the locales of cities and rural areas.

\section{Discussion}

The results present a complicated picture of the LGBT holdings of schools in two very different states. When examining the complete holdings list (of 110 titles), most of the variables considered here - locale of the school, political affiliation of the community, existence of a fairness ordinance, and demographic diversity - were not found to be significantly correlated with holdings. The only exception was the variable of enrollment for SO state; large schools held considerably more of the titles, on average, than small schools. Enrollment was also significant when examining titles with transgender themes. Locale proved to be an important variable regarding nonfiction titles.

Perhaps most striking was the overall similarity in holdings between the two States: very similar average holdings (22.5 for SO and 22.0 for $\mathrm{NE}$ ) and similar lists for the most frequently held books. There are a few possible ways to interpret this. First, it is possible that this is not a large enough sample. Two out of 50 states may not provide the wide diversity needed to determine the relevance of these variables.

Second, it is possible that the variables examined here (which were suggested in the literature) are just not good indicators of LGBT holdings in school media centers. It is possible that the variables of locale, political affiliation, existence of fairness ordinances, and demographic diversity do not have any relationship to LGBT holdings. The only exception, as found in this study, might be enrollment size of the school. However, enrollment size is often correlated with expenditures per student; smaller schools, for example, frequently have much smaller school media center budgets. Thus, perhaps the variable of enrollment size was indicating a nested variable having to do with expenditures. For this study, it was not possible to capture the annual expenditures of the school media centers, so this question will have to wait for subsequent research. Other variables that may be addressed in future research include the existence of a gay-straight alliance club at the school, explicit recognition and condemnation of LGBT bullying in school policies, collection size, and collection development policies of school media centers.

Finally, another possibility is that collecting LGBT titles is becoming more widespread in school media centers, regardless of factors such as locale, political affiliation, fairness ordinances, or demographic diversity. LGBT books are increasingly likely to be reviewed and recommended for purchase (e.g. Kelley 2013; see also numerous book reviews by Michael Cart in Booklist over the past few years); they are also increasingly likely to be included in approval plans. In the past 5years, the United States has seen a dramatic shift in public sentiment concerning LGBT citizens. This may be reflected in school librarians' willingness and ability to collect LGBT materials.

Further research could examine possible relationships between school library holdings of LGBT materials and LGBT bullying. Bullying has been a recurring theme in news headlines, has been intensely studied in recent years, and has been met with new resources and tools to combat it (e.g. http://www.stopbullying.gov). Several news stories in the past few years have reported the suicides of teens bullied about their supposed sexuality (James 2011; WSMV 2011; Braithwaite 2012; Chavez 2012; O’Donnell 2014; Williams 2013). Many studies about LGBT bullying note that there are concrete steps schools can take to reduce bullying; one step that is often mentioned includes "curricular resources (i.e. positive representations of LGBT issues in curriculum, access to LGBT information at schools)" (Perez et al. 2013, 66; see also Fedewa and Ahn 2011; Russell et al. 2011; Becnel 2013; Greytak et al. 2013; Kosciw et al. 2013). Future research could attempt to link anti-bullying policies in schools, LGBT materials in school media centers, and the occurrence (or non-occurrence) of LGBT-related bullying.

For example, one could examine the holdings of school media centers in locales where gay teen suicide occurred. One could study how school media center collections change as schools become more vigilant and 
proactive about bullying. One could track how often LGBT-themed books are shelf-read or checked out and see if there is correlation with incidents of bullying. Of course, this is not meant to suggest that there would be a simple, unidirectional, strong correlation between a school media center's LGBT collection, the student body's reading of those materials, and reduced incidence of teen LGBT bullying. Such correlation is unlikely to be found, yet there may well be some relationship there that can be found with future work.

\section{Conclusion}

The research discussed here examined the LGBT-related holdings of school media centers in two US states, one in the northeast and one in the south, with a list-checking exercise. The variables examined include enrollment size, type of locale, existence of a fairness ordinance, demographic diversity, and political affiliation. Only enrollment size, for the southern state, was found to be significantly correlated with the size of school libraries' collections: schools with large enrollments were more likely to have a higher average number of books. When looking only at books from the list with a transgender theme, enrollment became a significant variable in both states. When looking only at nonfiction books from the list, enrollment was significant in both states and locale was additionally significant for the southern state. This data begins to paint the picture of LGBT holdings in school media centers.

Acknowledgment: This research was assisted by the Applied Statistics Lab and benefitted from readings by Stacy Kowalczyk and Lisa O’Connor.

\section{References}

Becnel, K. 2013. "Sticks, Stones, and Sneering Tones: The Librarian's Role in Ending the Bullying Epidemic." Children and Libraries 11 (3): 10-15.

Boon, M. H., and V. Howard. 2004. "Recent Lesbian/Gay/Bisexual/ Transgender Fiction for Teens: Are Canadian Libraries Providing Adequate Collections?" Collection Building 23 (3): 133-38.

Braithwaite, L. B. 2012. "Gay Michigan Teen Josh Pacheco Commits Suicide over Bullying." Queerty.com. Accessed December 10, 2014. http://www.queerty.com/gay-michigan-teen-joshpacheco-commits-suicide-over-bullying-20121205/.

Chavez, A. M. 2012. "El Paso Gay Teen Commits Suicide after Being Bullied.” El Paso Times, June 13. Accessed December 10, 2014. http://www.elpasotimes.com/newupdated/ci_20847745/elpaso-gay-teen-commits-suicide-after-being.

Clyde, L. A., and M. Lobban. 2001. "A Door Half Open: Young People's Access to Fiction Related to Homosexuality." School Libraries Worldwide 7 (2): 17-30.

Downey, J. 2013. "Self-Censorship in Selection of LGBT-Themed Materials." Reference and User Services Quarterly 53 (2): 104-7.

Fedewa, A. L., and S. Ahn. 2011. "The Effects of Bullying and Peer Victimization on Sexual-Minority and Heterosexual Youth: A Quantitative Meta-Analysis of the Literature.” Journal of GLBT Family Studies 7 (4): 398-418.

Gardes, T. 2008. "Serving Lesbian, Gay, Bisexual, Transgendered, and Questioning Teens in Your Library Media Center." California State Library Association Journal. 32 (1): 23-24.

Gates, G. J., and A. M. Cooke. 2011. "United States Census Snapshot: 2010. The Williams Institute." Accessed December 10, 2014. http://williamsinstitute.law.ucla.edu/wp-content/ uploads/Census2010Snapshot-US-v2.pdf.

Greyson, D. 2007. "GLBTQ Content in Comics/Graphic Novels for Teens." Collection Building 26 (4): 130-34.

Greytak, E. A., J. G. Kosciw, and M. J. Boesen. 2013. "Putting the 'T' in 'Resource:' the Benefits of LGBT-Related School Resources for Transgender Youth.” Journal of LGBT Youth 10 (1-2): 45-63.

Hughes-Hassel, S., E. Overberg, and S. Harris. 2013. “Lesbian, Gay, Bisexual, Transgender, and Questioning (LGBTQ)-themed Literature for Teens: Are School Librarians Providing Adequate Collections?" School Library Research 16. Accessed December 10, 2014. http://www.ala.org/aasl/sites/ala.org.aasl/files/ content/aaslpubsandjournals/str/vol16/ SLR_LGBTQThemedLiteratureforTeens_V16.pdf.

James, S. D. 2011. "Gay Buffalo Teen Commits Suicide on Eve of National Bullying Summit." ABC News, September 21. Accessed December 10, 2014. http://abcnews.go.com/Health/gay-buffalo-teen-commits-suicide-eve-national-bullying/story? id $=14571861$.

Jenkins, C. A. 2008. "Book Challenges, Challenging Books, and Young Readers: The Research Picture.” Language Arts 85 (3): 228-36.

Kelley, A. 2013. "Calling All Gender Identities." Booklist 110 (4): 58. Kosciw, J. G., N. A. Palmer, R. M. Kull, and E. A. Greytak. 2013. "The Effect of Negative School Climate on Academic Outcomes for LGBT Youth and the Role of in-School Supports." Journal of School Violence 12 (1): 45-63.

Lang, M. 2009. "Library Rhetoric: The Canadian Library Association Statement of Diversity and Inclusion and LGBTQ Advocacy." Progressive Librarian 32 (Winter/Spring): 36-54.

Lukenbill, W. B. 2007. "Censorship: What Do School Library Specialists Really Know? A Consideration of Students' Rights, the Law and Implications for a New Education Paradigm." School Library Media Research, 10. Accessed December 10, 2014. http://www.ala.org/aasl/sites/ala.org.aasl/files/ content/aaslpubsandjournals/str/vol10/SLMR_Censorship_ V10.pdf.

Martin, H. J., and J. R. Murdock. 2007. Serving Lesbian, Gay, Bisexual, Transgender and Questioning Teens: A How-to-Do-It Manual for Librarians. New York, NY: Neal-Schuman Publishers.

Mehra, B., and D. Braquet. 2011. "Progressive LGBTQ Reference: Coming Out in the 21st Century." Reference Services Review 39 (3): 401-22. 
Mehra, B., and D. Braquet. 2006. “A ‘Queer' Manifesto of Interventions for Libraries to 'Come Out' of the Closet! A Study of 'Queer' Youth Experiences during the Coming out Process." Libres: Library and Information Science Research Electronic Journal 16 (1). Accessed December 10, 2014. http://libresejournal.info/848/.

Moss, E.2008. "An Inductive Evaluation of a Public Library GLBT Collection." Collection Building 27 (4): 149-56.

National Center for Education Statistics. 2006. "Identification of Rural Locales.” Accessed December 10, 2014. http://nces.ed. gov/ccd/rural_locales.asp\#defs.

Norton, T. L., and J. W. Vare. 2004. “Literature for Today's Gay and Lesbian Teens: Subverting the Culture of Silence." The English Journal 94 (2): 65-69.

Oberg, L. R., and G. M. Klein. 2003. "Gay-Themed Books in Oregon Public and Academic Libraries: A Brief Historical Overview." Oregon Library Association Quarterly 9 (2): 8-12.

O’Donnell, M. H. 2014. “Pocatello High School Rock Honors Suicide Victim: Family Says Teen was Bullied for Sexual Orientation.” Idaho State Journal, February 25. Accessed December 10, 2014. http://www.idahostatejournal.com/members/pocatello-highschool-rock-honors-suicide-victim-family-says-teen/article_01e4b9d4-9dfe-11e3-931e-001a4bcf887a.html? mode $=$ story.

Perez, E. R., G. T. Schanding Jr, and T. K. Dao. 2013. “Educators' Perceptions in Addressing Bullying of LGBTQ/Gender Nonconforming Youth." Journal of School Violence 12 (1): 64-79.

Rauch, J. 2010. "Red Families, Blue Families, Gay Families, and the Search for a New Normal." Law and Inequality: A Journal of Theory and Practice 23 (2): 333-44.

Rauch, E. W. 2011. "GLBTQ Collections Are for Every Library Serving Teens." Teacher Librarian 39 (1): 13-16.

Ritchie, C. J. 2001. “Collection Development of Gay/Lesbian/ Bisexual-Related Adult Non-fiction in Medium-Sized Illinois Public Libraries." Illinois Libraries 83 (2): 39-70.
Rossi, N. E. 2010. “'Coming Out'Stories of Gay and Lesbian Youth Adults.” Journal of Homosexuality 57 (9): 1174-91.

Russell, S. T., C. Ryan, R. B. Toomey, R. M. Diaz, and J. Sanchez. 2011. "Lesbian, Gay, Bisexual, and Transgender Adolescent School Victimization: Implications for Young Adult Health and Adjustment." Journal of School Health 81 (5): 223-30.

Savage, T. A., and G. T. Schanding Jr. 2013. "Creating and Maintaining Safe and Responsive Schools for Lesbian, Gay, Bisexual, Transgender, and Queer Youths: Introduction to the Special Issue." Journal of School Violence 12 (1): 1-6.

Stringer-Stanback, K. 2011. "Young Adult Lesbian, Gay, Bisexual, Transgender, and Questioning (LGBTQ) Non-fiction Collections and Countywide Anti-discrimination Policies." Urban Library Journal 17 (1). Accessed December 10, 2014. http://works. bepress.com/cgi/viewcontent.cgi? article $=1005 \&$ context $=$ kynita_stringer_stanback.

Vaillancourt, S. 2013. “Libraries as Safe Spaces.” American Libraries 44 (1-2). January-February, 30. Accessed December 10, 2014. http://www.americanlibrariesmagazine.org/issue/januaryfebruary-2013.

Walton, G. 2004. "Bullying and Homophobia in Canadian Schools: The Politics of Policies, Programs, and Educational Leadership." Journal of Gay and Lesbian Studies in Education 1 (4): 23-36.

Webber, C. K. 2010. Gay, Lesbian, Bisexual, Transgender, and Questioning Teen Literature: A Guide to Reading Interests. Santa Barbara, CA: Libraries Unlimited.

Williams, M. E. 2013. “Another Bullied Gay Teen Commits Suicide.” Salon.com, January 30. Accessed December 10, 2014. http:// www.salon.com/2013/01/30/another_bullied_gay_teen_ commits_suicide/.

WSMV. 2011. "Friends Say Classmate Killed Self after Bullying on Sexuality." WSMV.com, December 7. Accessed December 10, 2014. http://www.wsmv.com/story/16213348/friends-sayclassmate-killed-self-after-bullying. 